\title{
"Until I Die, I will Sing My Calypso Song": Calypso, Soca, and Music Education Across a Generational Divide in Grenada, West Indies
}

\author{
Danielle Sirek \\ University of Windsor, Ontario, Canada
}

In post-revolution Grenada, explorations of identity often reveal a generational divide. This generational divide is frequently expressed through music (Sirek 2013, 2018). In this qualitative case study I use an ethnographic methodological approach to examine Grenadian calypso and soca music, analyzing data collected from observations and participant observations, interviews, investigation of media/social media; as well as calypso and soca music and lyrics. Drawing from Tönnies' (1887/2017) constructs of Gemeinschaft and Gesellschaft, I explore the ways in which calypso and soca musicking (Small 1998) and music education initiatives construct and articulate the generational divide in Grenada.

Keywords: calypso, soca, Grenada, Gemeinschaft and Gesellschaft, identity, music education

I

n present day Grenada, West Indies, explorations of identity often reveal a generational divide between older and younger Grenadians (Shemer 2012, Sirek 2013). The older generation of Grenadians includes those born before the Grenada revolution (1979-1983) and subsequent American invasion (1983); and the younger generation of Grenadians includes those who were very young or born after the revolution and invasion. In this qualitative case study, I explore the ways in which calypso and soca musicking (Small 1998) and music education initiatives construct and articulate the post-revolution generational divide in Grenada.

The role of calypso music is significant in Grenadian folk culture. ${ }^{1}$ It is widely believed that calypso originated with the tradition of the West African griot, whose responsibility was to sing the history of the community, remind people of social orders and ideals, and provide social commentary through song (Gallaugher 1991,

(C) Sirek, D. The content of this article is the sole responsibility of the author. The ACT Journal and the Mayday Group are not liable for any legal actions that may arise involving the article's content, including, but not limited to, copyright infringement. 
Liverpool 1993). Enslaved West Africans brought this tradition to Grenada and elsewhere in the Caribbean. Following in this convention, calypso lyrics are nearly always social or political in nature; and before literacy was commonplace in Grenada, Grenadians would gather in community calypso tents to hear the news of the day via calypso performances. Contemporary calypsos are inflected by French, English, and Spanish song forms, are upbeat and repetitive, and follow expectable conventions in form, harmonic structure, and syncopated rhythmic idioms.

Soca, a musical genre that grew out of a fusion of calypso and East Indian rhythms from Trinidad, is the music of the youth in Grenada. Socas are fast, driving, and highly repetitive; and assembled using drum machines, synthesizers, sequencers, samplers, digital multitracking, and autotune. They receive the most radio airplay of any genre in Grenada, and generate large sums of money in revenue at concerts every year. The message of soca exists in the beat and in the body, with lyrics usually emphasizing pleasures of the individual: partying, sex, and alcohol. ${ }^{2}$ Soca performance style includes audience participation, which takes the form of jumping, wining (wining is a type of dance in which the waist is provocatively moved in a circular motion), waving flags and rags, singing along, and shouting and cheering to support the soca artiste. 3 In soca, it seems that nothing matters except this sense of abandonment and escape from reality-the here and the now: this place, this dance, these people, and this experience.

Older Grenadians often view calypso as being both representative and constitutive of "traditional" Grenadian identity and Grenadian values. However, many young people do not feel that calypso music reflects contemporary Grenadian identity, despite usually viewing it as an integral part of their cultural heritage. Younger Grenadians, who articulate feeling distanced from calypso's social and political commentary, embrace the soca music that, for them, represents a modern, globalized Grenadian identity. Older Grenadians, conversely, frequently reject soca for its perceived associations of immorality and apathy (Sirek 2013). Although many Grenadians participate in musicking that contrasts with the group to which they "belong," it is helpful to make such distinctions since the following discussion of the relationship between Grenadian identity and musicking concerns older and younger people in Grenada. More broadly, the distinction between those who engage with calypso and those who engage with soca reflects and constitutes social distinctions between old and young, colonized and free, religious and secular,

Sirek, Danielle. 2018. "Until I Die, I will Sing My Calypso Song”: Calypso, Soca, and Music Education Across a Generational Divide in Grenada, West Indies. Action, Criticism, and Theory for

Music Education 17 (3): 12-29. doi:10.22176/act17.3.12 
and-as I will argue-Gemeinschaft and Gesellschaft; sociologist Ferdinand Tönnies' (1887/2017) notions of kinship-community and individualistic society.

\section{Historical context: The Grenada revolution and American invasion}

Here, I give a very detailed account of the final moments of the Grenada revolution and subsequent American invasion, so that my reader may have context for the generational divide in Grenada. Politically, Grenada has had a turbulent history of revolution and invasion. After the genocide of Grenada's Indigenous peoples by French colonizers, enslaved persons were brought to the island in the mid-160os from the African continent. Grenada was alternately claimed by France and Britain between 1650 and 1783, and was under British rule between 1783 and 1974. On February 7 th, 1974, the island claimed independence. Following a nearly 30-year dictatorship under Eric Matthew Gairy that began pre-independence, a MarxistLeninist revolution took place in 1979, led by Maurice Bishop. The revolution was hugely successful, and the majority of Grenadians supported the People's Revolutionary Government and their objectives (Meeks 1993, Pryor 1986). During this time, much advancement was made in infrastructure, education, and social welfare.

In October 1982, when the revolution was in its third year, Deputy Prime Minister Bernard Coard resigned from the Central Committee of the People's Revolutionary Government, feeling that the leadership was operating contrary to MarxistLeninist principles. In so doing he created an irreparable schism between Prime Minister Maurice Bishop, and the "Coard faction." Over the next year, governmental relationships became increasingly strained. In October 1983, Prime Minister Bishop was expelled from the Central Committee and placed illegally under house arrest along with Jacqueline Creft, another leader of the New Jewel Movement with whom Bishop was romantically involved. News of their detention spread across the island quickly, and on October 19th, approximately 15,000 Grenadians-about 15 percent of the total population-assembled in St. George's Market Square in protest. Of these demonstrators, several thousand (of whom many were youth) went to Bishop's home. Upon realizing that the guards had been ordered not to shoot the public, the people stormed the house, freeing Bishop and Creft.

After being freed, Bishop requested to be taken to Fort Rupert, the main military installation near St. George's, instead of to Market Square where the crowd

Sirek, Danielle. 2018. “Until I Die, I will Sing My Calypso Song”: Calypso, Soca, and Music Education Across a Generational Divide in Grenada, West Indies. Action, Criticism, and Theory for Music Education 17 (3): 12-29. doi:10.22176/act17.3.12 
was waiting to hear him speak. The demonstrators were given the keys to the armory, and the distribution of arms to "trained" civilians commenced. Marable (1987) gives the following account of what happened next:

About one o'clock, a troop carrier and two Soviet-built armored cars descended on the fort. There is conflicting evidence whether the PRA ${ }^{4}$ or the crowd fired first, but the fact that heavily-armed soldiers were sent indicates that the Coard faction was fully prepared to crush all resistance. After the firing began, Bishop ordered his supporters to surrender. But in only minutes, several PRA soldiers were killed and over one hundred civilians, including many children (261).

Despite having surrendered, Prime Minister Bishop and many of his close associates were executed; and the island was put under 24-hour curfew. Those who broke curfew risked being shot on sight (Austin 1983).

At 5:Ooam on October 25th, 1983, 6 days after Bishop's execution, the United States under President Ronald Reagan along with troops from Jamaica, Barbados, Antigua, Dominica, St. Kitts and Nevis, St. Lucia, and St. Vincent invaded Grenada. After four days of resistance, the Grenadian People's Revolutionary Army and Cuban soldiers on the island surrendered. The American invasion concluded on November 2nd, 1983, and the United States installed a temporary government that remained in power for the next nine months. Presently, Grenada operates under a democratic bicameral parliamentary system, with a 15-member elected House of Representatives and a 13-member appointed Senate, as well as a prime minister, governor general, and cabinet.

\section{Gemeinschaft and Gesellschaft, identity, and musicking}

Community as a sociological concept has been explored by a number of scholars including Marx, Weber, Durkheim and Tönnies. In this paper, I draw from sociologist and philosopher Ferdinand Tönnies' (1887/2017) theoretical ideas of Gemeinschaft and Gesellschaft. Gemeinschaft-usually translated into English as "community"-is the result of natural/essential will (Wesenwille) and is based on social interactions, emotion, and kinship. It is maintained through loyalty and sentiment, rather than efficiency and productivity, and is usually associated with "traditional” culture. Conversely, Gesellschaft (Kürwille)-usually translated into English as "society"-is characterized by individualism and self-interest; steered by rational will; mediated by market and money; and guided by impersonal interactions, indifference, and competition. Tönnies (1887/2017) argued that social

Sirek, Danielle. 2018. “Until I Die, I will Sing My Calypso Song”: Calypso, Soca, and Music Education Across a Generational Divide in Grenada, West Indies. Action, Criticism, and Theory for

Music Education 17 (3): 12-29. doi:10.22176/act17.3.12 
relationships upon which Gemeinschaft is based are becoming subordinate to the rational will of Gesellschaft. While in Tönnies' writings these two groups were developed as ideal types and are often presented as a dichotomy, he also discussed the "Gemeinschaft-like" and "Gesellschaft-like".5

For Tönnies (1887/2017), Gesellschaft resists and repels Gemeinschaft with detestation:

But it is in the organization and order of the Gemeinschaft that folk life and folk culture persist. The state, which represents and embodies Gesellschaft, is opposed to these in veiled hatred and contempt, the more so the further the state has moved away from and become estranged from these forms of community life. $(224-5)$

Tönnies' theory of Gemeinschaft and Gesellschaft is helpful in analyzing the generational divide in contemporary Grenada. I posit that this generational divide is in part due to an older generation of Grenadians identifying with and subscribing to the ideology of Gemeinschaft (community), while younger Grenadians identify with and subscribe to the ideology of Gesellschaft (society).

Identity is both representative-for example, culture, age, gender and sexuality, role; and constructive-for example, present identity as influencing future identity. It is understood through reference ("I am/as") as well as difference ("they are"); and in this way is also relational. Self-concept-perception of oneself-is formed through people's experiences with the world around them (Shavelson, Hubner, and Stanton 1976); and social identity is one's self-concept as it relates to membership of a social group. As individuals identify with certain groups, this association becomes part of their process of identity construction (Mueller 2002). In Grenada, as everywhere, social identity is frequently presented and constructed through acts of musicking. Musicking, as conceived by Christopher Small (1998), reconceptualizes music as an action rather than a "thing." It is not the same as, and should not be confused with, "making music" or "performing," since these words only apply to the actions of music performers; musicking is instead something that all people present in some way take part. Inherent in Small's theory of musicking is a focus on how and why through music, people can "explore, affirm, and celebrate" desired (what he calls "ideal") relationships. A view that gives precedence to the act of doing music rather than the musical object, and of relationships, allows a particular understanding of the negotiation of identities within the Grenadian population.

Sirek, Danielle. 2018. "Until I Die, I will Sing My Calypso Song”: Calypso, Soca, and Music Education Across a Generational Divide in Grenada, West Indies. Action, Criticism, and Theory for

Music Education 17 (3): 12-29. doi:10.22176/act17.3.12 


\section{Methodological approach}

The study was conceived as a qualitative case study in which I use ethnographic approaches and the dual lenses of music educator and ethnomusicologist. Case study provides an opportunity to explore in detail events, people, programs, and/or places in a very specific, deliberate, and contextual way, so as to lead to a deeper understanding of a complex issue in which the case is involved. The uniqueness of a case study may then contribute to larger, broader understandings.

For eleven months, June 2010 to May 2011, I lived and worked in Grenada, West Indies, just outside of the capital city of St. George's. I taught general music in three schools and an orphanage, was involved with two adult choirs and one young adult choir, and attended many cultural festivals and concerts. During this time, I kept a researcher diary of field notes of observations and participant observations, and also took still, audio, and video recordings of music performances and festivals. During the last two months of my stay in Grenada, I conducted formal semi-structured interviews with nearly 100 informants who either were Grenadian by birth, or who had lived in Grenada for several years. Informants identified as both "musicians" and "non-musicians," were diverse in age and demographic, and included soca artistes and calypsonians; ${ }^{6}$ officials from the Government of Grenada and the Grenada Carnival Committee (Spicemas Corporation), community choristers, church musicians, gospel singers, choir directors, jazz musicians, reggae singers, folklorists, historians, members of the Royal Grenada Police Force Band, steel pan players, a panmaker, and numerous "non-musician" music enthusiasts. Interviewing this wide array of people was purposefully done so to provide a wide-ranging picture of music and identity in Grenada. After my time in the field, I continued to follow Grenadian YouTube channels, news, and social media over a period of 6 years (2011-2017). YouTube channels included Gentle Benjamin (GBTV CultureShare Archives), 1socaholic, Greenzking Promoz, NOW Grenada, and the Grenada Broadcasting Network. Facebook groups and pages included Grenadian Culture, I Love Grenada, Spicemas Corporation (former Grenada Carnival Committee), Grenada Steel Pan events, Pan Wizards....Bad Like Yaaz, and Tivoli Drummers. In addition to these, I followed Grenadian friends' and colleagues' personal Youtube channels and Facebook pages. This online study was informed by and expands on the ethnographic data collected in the field.

Using Lars Eckstein's (2010) interpretive analytical methodological framework for song lyric analysis, I analyzed calypso and soca music as "performed

Sirek, Danielle. 2018. "Until I Die, I will Sing My Calypso Song”: Calypso, Soca, and Music Education Across a Generational Divide in Grenada, West Indies. Action, Criticism, and Theory for

Music Education 17 (3): 12-29. doi:10.22176/act17.3.12 
literature."7 Drawing explicitly from Christopher Small (1998), Eckstein (2010) argues that lyrics are fundamentally "performance art"-the meaning lies not in lyrics-as-object, but rather, in acts of, as Small says, "creating, displaying, and perceiving” (Small 1998 in Eckstein 2010). Lyrics, according to Eckstein (2010),

cannot be conceived outside of the context of their vocal (and musical) actualisation-i.e. their performance ... We may encounter songs in a myriad of medial formats and generic situations ... yet in all cases, language is given the body of a voice and saturated in musical sound; and when it is not, as in printed lyrics, it is meant to be sounded. (10)

Eckstein advocates for the reading of diverse "texts" across disciplinary boundaries to make meaning in lyrics. Much like works of art, meaning is inflected by context and convention; and interpretation of lyrical content is conditional to the positionality ${ }^{8}$ of the reader and the reader's interaction with the text. Using Eckstein's approach, I examine calypso and soca lyrics taking in performance, voice, convention, and experience.

Data from field notes, recordings, and interview transcriptions were examined using a constructivist approach, which takes social phenomena as being in a constant state of production and revision; and guided by interactions. Within this exists a subjective and transactional epistemology where understandings are coconstructed; and methods that support a naturalistic, dialectical, and hermeneutically-based methodology (Guba and Lincoln 1998). In this context, hermeneutics is defined as "interpretation" (Bartel 2005), requiring a constant "spinning out" of ideas whereby particulars are understood only in context of the whole (Phelps et al. 2005, 103); and in which various ideas are always in conversation with each other. Data was collated and analyzed for themes including "identity," "culture," "older/younger generation," "calypso," and "soca." Further follow-up correspondence with informants crystallized (Richardson 1997) the findings presented below.

\section{Calypso, soca, and music education across a generational divide}

The calypso/soca divide is supported in previous research. Robin Balliger (2000) offers,

Calypso represents the generation who successfully fought colonialism, but for whom independence also meant succeeding in the terms and values of Western modernity-the importance of speech being central-speech as a sign of intellect and power in an emerging post-colonial, public sphere. To briefly extend this

Sirek, Danielle. 2018. "Until I Die, I will Sing My Calypso Song”: Calypso, Soca, and Music Education Across a Generational Divide in Grenada, West Indies. Action, Criticism, and Theory for

Music Education 17 (3): 12-29. doi:10.22176/act17.3.12 
structural analysis, calypso/soca represents national/transnational, old/young, mind/body, civilized/savage (22).

Ryan et. al. (2013) argue that,

While the calypso as an art form has been influential in drumming up social awareness of issues, the impact of calypso has since declined ... what seems to typify the [soca] music of this society [of young people] is that it is fast paced and driven by a frenetic energy that is at the same time mindless, yet controlling of the emotions and energy of the crowd. (47)

Informants told me that while younger people usually view calypso as a fundamental part of their culture, calypso is seen as out of touch with the perceptions, values, and lived experiences of the youth. Samson,9 a young gospel singer, acknowledged calypso as "our" music, but expressed that younger people find it boring:

Our own music, we're not hearing it ... if you put it on, they will say like, "that's boring, man.”

This disdain for calypso music is not only an expression of musical like or dislike, but also indicates a disdain for that which is represented and constituted by calypso: social concern and traditional values.

Ajamu's iconic song "My Calypso," written six years after the American invasion, illustrates the changing role of calypso music in Grenada in the late 1980s. In this performance, Ajamu, clad in a gold lammé suit and matching hat, sings almost pleadingly to his listeners: " $m y$ calypso, sweet calypso music, until I die I will sing my calypso song ... to fight evil forces down." Later in the song, Ajamu reminds his audience of the history of calypso: its roots lie in shared history of enslavement and toil, but also in the resistance and power of their community. Ajamu goes on to sing that calypso will "open freedom's door"-hearkening back to the enslaved past while bringing this experience of oppression to the present. He earnestly promises to fight for calypso, even, apparently, at great personal expense-offering to put his neck on a block; and threatening to "give licks" to Grenadians who treat calypso or calypsonians poorly. He concludes by acknowledging the great difficulty in fighting for calypso music and restoring it to its former place of glory. He compares himself, the calypsonian fighting for an artform ${ }^{10}$ in danger, to a "little" axe meant to cut down a big tree, or to David, from the biblical story of David and Goliath-small, but ultimately, more powerful than anything that might stand in his way. Such tropes would surely not be lost on his audience-insider language and double 
entendre are conventions of the artform, as is the social commentary illustrated below. The links Ajamu makes to the enslaved past and to the oppression of the Grenadian people are effective ways of promoting traditional Grenadian identity and Gemeinschaft notions of community. Lyrics reference collective experience resisting enslavement ("an oppression on the slave ship" and "we had no choice but to sing calypso song") and the sacrifices of one for the many ("I'll put my neck on a block"). I have transcribed this song, and the soca song that follows, using Grenadian spelling conventions in consultation with informants.

An oppression on de slave ship

When de master strike with his whip

And when dey workin'so hard in de sun, Yes, we had no choice, but to sing calypso song!

So I'm going to sing my calypso, sing my calypso

I'll sing it for the rich, and for the poor, and everywhere I go!

I'm going to sing, I'm going to sing, I'm going to sing, yes,

I'm going to sing my calypso!

I know for sure it would ${ }^{11}$ open freedom door.

One more ting, before I go

I must let you know

As a man I would stand up strong and fight for calypso

I'll put my neck on a block and I'll swear man, and so help me God, good God

I'm going to lick you if you treat my calypso bad

So you better beware of de things you say

Cuz not a man shall escape

As small as you see me

But little axe does cut down big, big tree

And if you is Goliath, well King David-that's me! $!^{12}$

Calypso, and its associations of kinship and loyalty as articulated through social commentary and amplification of collective experience (e.g. community performance venues, shared performance practice) both reflect and construct notions of Gemeinschaft for older Grenadians. Calypso represents their past, their voice, and their identity as they perceive it to be-one based on traditional culture and community values. It is unsurprising, therefore, that many older Grenadians promote the teaching, learning, and performance of calypso music through youth calypso competitions, calypso workshops, and calypso teaching initiatives in schools. For example, in 2013, the Grenada Union of Teachers (G.U.T.) Credit Union launched the "Pass the Torch Calypso Program" in which top Grenadian calypsonians like Scholar and Black Wizard were engaged to teach calypso writing and performance to young musicians. G.U.T. Credit Union has also hosted several youth 
calypso competitions, in which young calypsonians sing their calypsos to win prize money. In an interview in 2017, Camille Goddard, Communications Manager for G.U.T. Credit Union, expressed that the purpose of the "Pass the Torch Calypso Program" and other G.U.T.-sponsored calypso events was to ensure that the country's "culture and heritage is not lost" (Grenada Broadcasting Network 2017). The explicit sentiment of G.U.T. Credit Union is that such a program is an "investment" in the nation's future. Here, the teaching and learning of calypso music is implicitly seen as also the teaching and learning of traditional Grenadian identity: without such programs, culture and heritage will be lost, and perhaps so too will the youth of the nation be "lost."

One can also take several meanings from the name "Pass the Torch" itself-it is a passing on of knowledge and experience from an older generation to a younger generation. But there is also significance in the torch symbol: according to one informant, flambeaux-cloths that are dipped in kerosene, tied to a piece of wood, and set alight-were the main source of light for enslaved Grenadians while they worked on plantations. The expression to "light the flambeaux" is to, according to Noel,

light the fire in the bellies of our ancestors ... it is the ignition of drive of the ancestors within oneself to fight oppression.

"Passing the torch," figuratively and literally, is one example of how connections to family and community are created and recreated.

The Ministry of Culture ${ }^{13}$ has also hosted several calypso teaching and learning initiatives in recent years. In 2011, Senator Arley Gill announced a pilot project that would involve a series of calypso outreach workshops on the teaching, writing, and singing of calypso music. This initiative was part of the UNESCO-sponsored Carnival Arts Program (CAP) of the Ministry of Education (Government of Grenada 2011). In 2015, calypso workshops for primary and secondary school students took place at three different locations. While schools throughout the region have put on calypso performance competitions for decades-calypsonian Black Wizard reports singing in them in the 1970s-these music education workshops focused upon learning how to write and sing calypsos; as well as learning about calypso's history and purpose. Of the workshops, calypso tutor at the Ministry of Culture Berkley Braithwaite said:

The workshop, basically, is to help promote the art form [sic] and to re-establish a basis for the continuation of quality calypso in Grenada. It will get more persons tion Across a Generational Divide in Grenada, West Indies. Action, Criticism, and Theory for Music Education 17 (3): 12-29. doi:10.22176/act17.3.12 
involved in the teaching of calypso writing, to preserve the artform by implementing it in schools. (NOW Grenada 2015)

In the calypso music education initiatives described above, there is a distinct focus on what informants identify as "preserving" and "saving" calypso; and on teaching young Grenadians "traditional” Grenadian culture. Such rhetoric perpetuates the idea that calypso musicking upholds the older generation as having the most authentic cultural knowledge and identity, based in kinship and community, and that this must be bestowed upon the younger generation.

While calypso may be understood as constructing and articulating Gemeinschaft for an older generation; soca music, and the focus upon advancement and globalization in Grenada, may be understood through the concept of Gesellschaft. While calypsos were traditionally performed in community tents with live bands (and are often still performed this way), socas are up-tempo melodies on top of sparsely-textured, pre-recorded digital "riddims" that are usually released online for mass consumption. They are inexpensive to produce-particularly since multiple socas will often be created using the same riddim-and are hugely popular both for Grenadians and tourists. Soca music releases often coincide with Carnival, the height of the tourist season, so that soca artistes may be considered for participation in the Soca Monarch competition that occurs during Carnival. Soca Monarch is the biggest music event on the island, and the first place winner receives between \$30,000 XCD-\$50,000 XCD (\$11,000 USD-\$18, ooo USD).

With its attendant themes of partying, sex, and alcohol, soca promotes pleasure of the individual. The 2012 soca song "Psycho" by Lavaman, with its pounding rhythm, exhorts the crowd to dance, jump, and wave "psychotically," embracing the fete (party) without care:

(Maniacal laughter) Voice: "Breaking news! Breaking news! A patient has just escaped from the mental institution!"

Show me any fete an' ah say

Once we see gyal'14 an' ah man dey

Ah say is more people in here

Mash it up, dey go, dey go

I'm a psycho! (If dey feel dey mad and dey troublesome)

I'm a psycho! (I eat ah hand grenade, ah lime, an' ah plum)

I'm a psycho! (I take off me shoes an' ah run it down)

I'm a psycho, tell them I'm a psycho, yes, I'm a psycho!

Over dey so, psycho, over here so, psycho 
All across so, psycho, all where we go, psycho

Man on woman, psycho, steelpan and iron, psycho

Jab and big band, psycho

Everybody, wave like a Grenadian, if yuh feeling like ah Vincentian

Wave like ah Trinidadian, if yuh feeling like ah Barbadian

Wave like ah Antiguan, if yuh feeling like ah Jamaican

Wave like ah, wave like ah!

Right at the beginning of the song, Lavaman emphasizes the corporeal, incorporating pre-recorded maniacal laughter accompanied by a mock news bulletin that warns the listener of an escaped mental patient, who presumably is dangerous and who lacks the capacity to do anything except, apparently, fete (party), be "troublesome," and compel onlookers to join him in "mashin' up de place." The repetition of the word "psycho" sends the message that the singer is immersed and submerged in the movement and music that he creates and by which he is surrounded, unable to see or do anything else because of his own madness. The song might, from some perspectives, be heard to address an audience of young Grenadian "psychos," caught up in the visceral sociability of feting and the euphoria of dance music.

Although multiple older informants expressed that soca music has no politically or socially meaningful content, this music provides commentary on the Grenadian youth context and experience (Balliger 2000, Moonsammy 2009). Renata suggested that soca could, in fact, be a means of expressing values, even if not overtly:

People could see [social commentary] in calypso, but the modern music [soca] has all sorts of things, and people don't see that. People will say, that's not like calypso, it's not serious, it's pure noise. And repetition. And instructions....

Soca is a way by which young people set up social boundaries that distance and alienate both older Grenadians, and associated traditional music and ideals. It speaks to a generation of Grenadians who are living in a vastly different world than that of their parents and grandparents: a Grenada that is global and technological, and heavily influenced by American culture and values. Grenadian youth turn to the "jump and wave" of soca music that promotes indifference and individual pleasure (Gesellschaft), rather than to calypso's intellectual critique of communitybased social and political concerns.

In 2011, the Schools Soca Monarch competition began as part of the previously-mentioned UNESCO-sponsored Carnival Arts Program, under the auspices 
of the Ministry of Education (Government of Grenada 2011). Schools Soca Monarch, which takes place the last week of the school term, started out as a soca competition for secondary school students but now includes primary school students (since 2014) and college students (since 2016) as well (Government of Grenada 2014, CC6 News Night 2016). The inclusion of primary school students was purposefully done to promote the competition as a more "school-based" activity, with the deliberate aim of "creating a more positive conception" (The New Today 2014). Part of the Schools Soca Monarch initiative included facilitators going into schools to run music education clinics on writing and performing soca music. In a press release, the Grenada Information Service (a department of the Office of the Prime Minister) described this particular initiative as "fall[ing] in line with the Ministry's thrust to groom the young ones in participating in cultural events" (GIS Spice Mornings 2011)-indicating clearly enough soca's role in the internationalization and commercialization of Grenada's cultural forms, and tourism.

The statement was neither appreciated nor embraced by many older Grenadians, for whom soca represents a rejection of morality and responsibility (Sirek 2013). Nonetheless, the Schools Soca Monarch competition was embraced by many young people and their schools as well as, evidently, the Grenadian government. The winners between 2011-2016 received prizes for themselves and their schools ranging from $\$ 3000 \mathrm{XCD}-\$ 10,000 \mathrm{XCD}$ ( $\$ 1100$ USD - \$3700 USD).

While soca music education initiatives seemingly run contrary to the sensibilities and ideology of older Grenadians, soca music performance brings possibility for significant financial gain. It is interesting to note, however, that Schools Soca Monarch did not take place in 2017 or 2018. This points to the many layers of controversy involved in soca musicking and music education initiatives, and ideologies of Gemeinschaft and Gesellschaft. One informant, Gerald, said:

Soca provides an opportunity to dance, to jump, to wine ${ }^{15}$-because we're not shy to wine! That's a part of our culture. And that, too, is a challenge, because you have persons who, and I wouldn't call them conservatives, really, I would even say they are hypocrites, because they would object to the wining of a child, wining of persons at Carnival Monday and Tuesday, but if you look at the Big Drum ${ }^{16}$ dance, it's about the hips. It's about the hips. So our tradition about utilizing that part of our bodies to respond to music is there, it's who we are as a people.

Gerald, who is a member of the Grenada Carnival Committee ${ }^{17}$ and has a vested interest in the success of events like Soca Monarch, compares soca and its associated dancing (wining) to the traditional Big Drum dance, a dance rooted in

Sirek, Danielle. 2018. "Until I Die, I will Sing My Calypso Song”: Calypso, Soca, and Music Education Across a Generational Divide in Grenada, West Indies. Action, Criticism, and Theory for

Music Education 17 (3): 12-29. doi:10.22176/act17.3.12 
ideas of African kinship and heritage. In linking these artforms, he also links their associated values. He argues that wining, which some see as not being "meaningful" or as being meaningful only in harmful ways, is integral to Grenadian culture, and that using the body as a response to music extends beyond dancing: it is rather a manifestation and embodiment of who they are-historically, as with movement in the Big Drum; and also presently. This puts soca and wining in a completely different light-not as meaningless and empty, but rather, as using the body as a means of heralding a sense of self and a sense of community in African-based music and movement. Here he links the old with the young, and the traditional with the modern, ostensibly attempting to place soca and its values in a context that is more palatable for those who find it objectionable.

\section{Final thoughts}

In this case study, I have drawn from Tönnies' (1887/2017) theory of Gemeinschaft and Gesellschaft to explore the ways in which the teaching, learning, and performance of calypso and soca music construct and articulate the generational divide in Grenada. Older Grenadians frequently use folk cultural practices to express traditional, community-based notions of Grenadian identity; this identity reflects the idea of Gemeinschaft. Conversely, younger people often use popular music to express a modern, globalized Grenadian identity; this identity reflects the idea of $G e$ sellschaft.

Calypso music reflects and constructs the ideology of Gemeinshaft in an older generation of Grenadians in the acknowledged community-based history of the calypso artform; traditional competitions in community tents; performance practice of communicating directly to the audience; and social and political commentary in lyrical content. Calypso music education initiatives also are bound up with notions of Gemeinschaft, with ongoing rhetoric of "preserving" or "saving" traditional Grenadian culture and values; and "passing the torch" of family and community. Conversely, soca music, in its digitization; mass production and consumption; and emphasis on pleasure of the individual reflects the ideology of Gesellschaft in a younger generation. Soca music education initiatives also promote Gesellschaft with a distinct focus on financial success. However, in some cases Grenadians participate in musicking (Small 1998) and music education initiatives that contrast with the group to which they "belong," or straddle both groups-particularly if

Sirek, Danielle. 2018. "Until I Die, I will Sing My Calypso Song”: Calypso, Soca, and Music Education Across a Generational Divide in Grenada, West Indies. Action, Criticism, and Theory for

Music Education 17 (3): 12-29. doi:10.22176/act17.3.12 
there is a perceived financial or social gain. This research illuminates the intertwined relationship between musicking, music education, and social identity in the Grenadian context.

\section{About the Author}

Danielle Sirek teaches in the Faculty of Education and School of Creative Arts at the University of Windsor, Canada. Prior to teaching in higher education, she taught preschool through grade 12 music in Canada and Grenada, West Indies. Sirek received her PhD from the Royal Northern College of Music, UK. She also holds a Bachelor of Music from Wilfrid Laurier University (Canada), and a Master of Music from the University of Toronto (Canada). Her teaching and research interests include music teacher education, intersections between music education and ethnomusicology, sociology of music education, and arts education for social justice. Danielle also sings with the JUNO-nominated Canadian Chamber Choir.

\section{References}

Austin, Hudson. 1983. Statement by General Hudson Austin on behalf of the Revolutionary Military Council. Radio Free Grenada broadcast (19 October).

Balliger, Robin. 2000. Noisy spaces: Popular music consumption, social fragmentation, and the cultural politics of globalization in Trinidad. $\mathrm{PhD}$ thesis, Cultural and Social Anthropology, Stanford University.

Barrett, Janet R. 2007. The researcher as instrument: Learning to conduct qualitative research through analyzing and interpreting a choral rehearsal. Music Education Research 9 (3): 417-33.

Bartel, Lee. 2005. Tell me a story! Canadian Music Educator 46 (3): 15-16.

CC6 News Night. 2016. Schools soca monarch. https://www.youtube.com/ watch?v=EKv1ek_EaiQ

Eckstein, Lars. 2010. Reading song lyrics. Amsterdam: Editions Rodopi.

Gallaugher, Annemarie. 1991. From Trinidad to Toronto: Calypso as a way of life. MA thesis, Faculty of Music, University of Toronto.

GIS Spice Mornings. 2011. Aired 8th May 2011 on the Grenada Information Service.

Government of Grenada. 2011. Unesco [sic] assists Grenada with New Carnival Arts Program. http://www.gov.gd/egov/news/2011/mar11/16_03_11 /item_2/unesco_grenada_carnival_arts_program.html. 
Government of Grenada. 2014. School soca monarch open to primary school students. http://www.gov.gd/egov/news/2014/jun14/11_06_14/item_2/school _soca_monarrch_open_primary_school_students.html

Grenada Broadcasting Network. 2017. Junior Calypso Competition. https://www.youtube.com/watch?v=s1NqRfX1WJk

Guba, Egon G., and Yvonna S. Lincoln. 1998. Competing paradigms in qualitative research. In The landscape of qualitative research, edited by N. K. Denzin and Y. S. Lincoln, 105-17. Thousand Oaks: Sage.

Liverpool, Hollis Urban. 1993. Rituals of power and rebellion: The carnival tradition in Trinidad and Tobago, 1783-1962. PhD thesis, University of Michigan.

Marable, Manning. 1987. African \& Caribbean politics: From Kwame Nkrumah to the Grenada revolution. Redhill: Verso.

Meeks, Brian. 1993. Caribbean revolutions and revolutionary theory: An assessment of Cuba, Nicaragua, and Grenada. London: The MacMillan Press.

Moonsammy, Patricia A. 2009. Rapso warriors: Poetic performance, revolution, and conscious art music in Trinidad and Tobago. PhD thesis, Anthropology, University of Michigan.

Mueller, Renate. 2002. Perspectives from the sociology of music. In The new handbook of research on music teaching and learning, edited by Richard Colwell and Carol Richardson, 584-603. New York: Oxford University Press.

NOW Grenada. 2015. Calypso workshop for students. NOW Grenada. http://www.nowgrenada.com/2015/o5/calypso-workshop-for-students/

Phelps, Roger P., Ronald H. Sadof, Edward C. Warburton, and Lawrence Ferrara. 2005. A guide to research in music education. Lanham: Scarecrow.

Pryor, Frederic L. 1986. Revolutionary Grenada: A study in political economy. London: Praeger.

Richardson, Laurel. 1997. Fields of play: Constructing an academic life. New Brunswick, NJ: Rutgers University Press.

Roulston, Kathryn. 2006. Mapping the possibilities of qualitative research in music education: A primer. Music Education Research 8 (2): 153-73.

Ryan, Selwyn, Indira Rampersad, Lennox Bernard, Patricia Mohammed, and Marjorie Thorpe. 2013. The influence of popular music culture on crime. In No time to quit: Engaging youth at risk. Executive report of the Committee on Young Males and Crime in Trinidad and Tobago, 46-50. St Augustine: University of the West Indies.

Sirek, Danielle. 2018. “Until I Die, I will Sing My Calypso Song”: Calypso, Soca, and Music Education Across a Generational Divide in Grenada, West Indies. Action, Criticism, and Theory for

Music Education 17 (3): 12-29. doi:10.22176/act17.3.12 
Shavelson, Richard J., Judith Hubner, and George Stanton. 1976. Self-concept: Validation of construct interpretations. Review of Educational Research 46: 407-41.

Shemer, Noga. 2012. Public Ideologies and Personal Meaning-Making in Postcolonial Grenada. PhD thesis, University of California.

Sirek, Danielle. 2013. Musicking and identity in Grenada: Stories of transmission, remembering, and loss. PhD thesis, Royal Northern College of Music.

Sirek, Danielle. 2016. Providing contexts for understanding musical narratives of power in the classroom: Music, politics, and power in Grenada, West Indies. Action, Criticism, and Theory for Music Education 15 (3): 151-79.

Sirek, Danielle. 2018. Our culture is who we are! "Rescuing" Grenadian identity through musicking and music education. International Journal of Music Education 36 (1): 47-57.

Small, Christopher. 1998. Musicking: The meanings of performing and listening. Hanover: University Press of New England.

The New Today. 2014. A broadened school soca monarch. http://thenewtoday.gd/local-news/2014/07/03/a-broadened-school-soca-monarch/

Tönnies, Ferdinand. 1887/2017. Community and society (Gemeinschaft und gesellschaft). New York: Routledge.

\section{Notes}

Folk culture in Grenada (sometimes also referred to as "traditional" or "grassroots" culture) is comprised of African- and European-based syncretic artforms that were historically culturally significant to the black working-class population. More specifically, folk cultural practices are comprised of both (1) African customs and cultural features enslaved Grenadians used to cope with the trauma of their situation; and (2) French and British customs and cultural features that the European colonizers brought with them to the island.

2 This is not to say that there are not soca songs that overtly address social and political issues through lyrical content. For example, in 2012 a man was beaten to death by Grenadian Police, an event that brought the nation to a standstill. Some soca artistes released recordings calling for justice, such as Ghage Maddis' "No Brutality" and Dymez' "Police Beating Man." Other soca songs, such as RSK's "Saltfish," highlight the increasing cost of staple Grenadian foods. However, soca songs that overtly discuss politics, economics, health, and other social issues are few and far between - they generally do not make an appearance in competitions such as Soca Monarch, and despite frequently having the same "sound," are less favored than the soca songs that have themes of drinking, partying, and sex. 
3 In Grenada, many singers and instrumentalists (particularly singers in the soca genre) are referred to as "artistes."

4 The People's Revolutionary Army.

5 Many sociologists have critically responded to Tönnies' work on Gemeinschaft and Gesellschaft, including Max Weber. Both Tönnies and Weber saw the transition between Gemeinschaft and Gesellschaft as a primary reason for the industrial revolution of the nineteenth century, though they differed in how they viewed this development. While Weber accepted Tönnies' basic theory, he contended that both Gemeinschaft and Gesellschaft have always existed, at once repelling one another and blending together.

6 i.e. someone who sings calypso music.

7 Eckstein draws here from Bowden (2001).

${ }^{8}$ A discussion of my positionality and ethical considerations as a white female researcher in Grenada is beyond the scope of this paper, but is explored in depth in other writing (Sirek 2013, 2016).

${ }_{9}$ All names have been changed to pseudonyms.

${ }^{10}$ Grenadians often refer to musical genres or cultural forms as "artforms" (often spelled as one word rather than two); i.e. the calypso artform.

${ }^{11}$ In Grenada, would is often used as a substitute for “will” (i.e. future tense).

${ }^{12}$ Lyrics from 5'20.

${ }^{13}$ Government officials are nearly all older generation Grenadians.

14 Girl.

15 i.e. wining, please see page 13 .

${ }^{16}$ The Big Drum is a ritual combining music and dance that is unique to Carriacou, a dependency island of Grenada dating back to at least the 1700s. In Big Drum, the participants perform ritual nation dances that display different moves based on and associated with one's real or assumed African ancestry.

${ }_{17}^{17}$ Now the Spicemas Corporation. 